\title{
FENOMENA PERNIKAHAN DINI DALAM PERSPEKTIF ISLAM (STUDI KASUS DI DESA KALIKUNING)
}

\author{
${ }^{1}$ Achrory, Siska Iriani \\ ${ }^{1}$ STKIP PGRI Pacitan \\ Email: siskairiani24@yahoo.ac.id
}

\begin{abstract}
Abstrak: Penelitian ini bertujuan untuk (1) mengetahui fenomena pernikahan dini dalam pandangan Islam, (2) mengetahui dampak dari pernikahan dini yang terjadi di desa Kalikuning. Penelitian ini merupakan penelitian kualitatif melalui pendekatan studi kasus dengan alasan peneliti ingin mengetahui masalah dalam individu, kelompok, program, organisasi dan peristiwa yang biasa terjadi didalam secara sistematis. Untuk mendapat data yang tepat, maka perlu ditentukan informan yang sesuai dengan kebutuhan data (purposive). Teknik pengumpulan data menggunakan wawancara, observasi, dokumentasi, dan triangulasi. Teknik analisis data dimulai dari reduksi data, data dislay yang tahap akhirnya yaitu tahap verifikasi. Hasil penelitian menunjukkan bahwa kasus pernikahan dini di desa kalikuning masih tergolong tinggi yakni lebih dari 50\% setiap tahunnya. Dampak pernikahan dini di desa kalikuning antara lain; Terhindar dari perbuatan zina, rendahnya pengetahuan warga Kaikuning akan perkembangan IPTEK dan Sumber Daya Manusia, meningkatnya angka pengagguran berdampak pada meningkatnya angka perantauan ke luar daerah.
\end{abstract}

Kata kunci: pernikahan dini, perspektif Islam

Title: The Case of Young Married In Islamic Perspectives

Authors: Achrory, Siska Iriani

Abstracts: This study aims to (1) find out of the young married case in Islamic perspektif (2) find out the impact of youth marriage that occurred in kalikuning. this research is a qualitative study with a case study. that researchers want to know the problems in individuals, groups, programs, organizations and ordinary events that occur in a systematic manner. data collection techniq used interviens, observation, documentation, and triangulation. the data anabsis techniq are: data reduction, the data dislay and the verification stage. The results showed that the cases of young married in Kalikuning more than 50\% in the year. The impact of the young merried in Kalikuning. hamlet includes; Avoiding adultery, the low knowledge of the citizens at kalikuning on the development of science and technology and buman resources, the increasing number of unemployment has an impact on the increase in the overseas migrants.

Keywords: Early marriage, Islamic perspective 


\section{PENDAHULUAN}

Di dalam Islam, pernikahan bukan sekedar persoalan cinta dan kasih sayang semata. Lebih dari itu, Islam mengajarkan agar dalam pernikahan tercipta keluarga sakinah mawaddah wa rahmah serta terbentuknya generasi yang lebih baik dari masa ke masa lewat keluarga. Untuk itu, menjalankan pernikahan membutuhkan proses dan membutuhkan usaha yang keras agar Keluarga Dalam Islam yang diinginkan dapat terwujud. Bahkan bisa menjadi Keluarga Bahagia Menurut Islam. Untuk itu, membutuhkan keilmuan, modal materi, dan tentunya niat yang lurus untuk beribadah kepada Allah SW'T.

Hasil kajian yang dilaksanakan oleh BKKBN, pada tahun 2010 Indonesia termasuk negara dengan persentase pernikahan usia muda tinggi di dunia (ranking 37) dan tertinggi kedua di ASEAN setelah Kamboja. Perempuan muda di Indonesia dengan usia10-14 tahun menikah sebanyak 0.2 persen atau lebih dari 22.000 wanita muda berusia 10-14 tahun di Indonesia sudah menikah. Jumlah dari perempuan muda 15-19 tahun yang menikah lebih besar jika di bandingkan dengan laki-laki muda berusia 15-19 tahun (11,7\% P:1,6\%L). Diantara kelompok umur perempuan 20-24 tahun lebih dari 56,2 persen sudah menikah. ${ }^{1}$ Hasil ini menunjukkan bahwa perlunya peranan pemerintah untuk mensosialisasikan mengenai resiko pernikahan dini.

Isu pernikahan dini saat ini marak dibicarakan. Seperti halnya kasus beberapa tahun yang lalu yaitu pernikahan Pujiono Cahyo Widianto atau sering disebutnya dengan syeh puji, seorang hartawan sekaligus pengasuh pesantren dengan anak asuhnya yang bernama Lutviana Ulfah. Pernikahan antara pria berusia 43 tahun dengan gadis belia berusia 12 tahun ini mengundang reaksi keras dari Komnas Perlindungan Anak. Bahkan dari para pengamat berlomba memberikan opini yang bernada menyudutkan. Umumnya komentar yang terlontar memandang hal tersebut bernilai negatif.

Di sisi lain Syeh Puji, begitu ia akrab disapa berdalih untuk mengader calon penerus perusahaannya. Dia memilih gadis yang masih belia karena dianggap masih murni dan belum terkontaminasi arus modernitas. Lagi pula dalam pandangan Syeh Puji, menikahi gadis belia bukan termasuk larangan agama.

Namun seiring perkembangan zaman, image masyarakat justru sebaliknya. Arus globalisasi yang pesat mengubah cara pandang masyarakat. Perempuan yang menikah di usia belia dianggap sebagai hal yang tabu. Bahkan lebih jauh lagi, hal itu dianggap menghancurkan masa depan wanita, memberangus kreativitasnya serta mencegah wanita untuk mendapatkan pengetahuan dan wawasan yang lebih luas.

1 BKKBN, Kajian Pernikahan Dini pada Beberapa Provinsi di Indonesia: Dampak Overpopulation, Akar Masalah dan Peran Kelembagaan di Masalab dan Peran Kelembagaan di Daerah, tahun 2010. 
Adapun Dusun Sono merupakan salah satu dusun yang berada di Desa Kalikuning Kecamatan Tulakan Kabupaten Pacitan. Wilayah ini sekitar $50 \mathrm{~km}$ dari Kota Pacitan. Informasi yang muncul, dusun ini memiliki prosentase tertinggi dalam hal pernikahan dini. Hal ini diperkuat oleh pengakuan salah seorang mahasiswi yang menjalankan study di salah satu perguruan tinggi swasta di Kabupaten Pacitan. Di masa akhir studinya mahasiswi tersebut hampir putus studi karena desakan orangtua untuk segera dinikahkan dengan tetangga yang berusia dibawahnya. Dilihat dari beberapa faktor yang mempengaruhi problematika ini, antara lain adanya tekanan dari orang tua yang merasa ketakutan anaknya jadi perawan tua dan tidak laku-laku. Kemudian didukung tingginya anak putus sekolah dan rendahnya minat belajar anak itu sendiri. Dusun sono dapat dikatakan wilayahnya masih pelosok dengan mayoritas penduduk yang masih primitif. Kita meyakini bahwa mbah buyut kita dulu banyak yang menikahi gadis di bawah umur. Bahkan jaman dulu, pernikahan di usia "matang" akan menimbulkan persepsi buruk di mata masyarakat. Perempuan yang tidak segera menikah justru akan mendapat tanggapan miring atau lazim disebut perawan tua yang orang dahulu mengistilahkan dengan "perawan kaseb".

Tingginya angka pernikahan dini berdampak buruk dalam berbagai hal, antara lain: meningkatnya angka pengagguran, munculnya perselingkuhan akibat sering terjadi percekcokan, pertengkaran antara kedua pihak, rusaknya moral remaja, serta tingginya angka perceraian disebabkan faktor emosi kedua fihak yang masih labil sehingga tidak dapat memelihara kerukunan dalam rumah tangganya. Padahal undang-undang untuk batasan minimum usia anak yang bisa menikah telah di berlakukan, akan tetapi hingga saat kasus ini masi saja terjadi.

Tren pernikahan dini hingga saat ini masih menjadi pro dan kontra. Ada juga orang tua yang menginginkan anaknya lulus sekolah, dewasa atau mapan terlebih dulu. Ada kekhawatiran terhadap gagalnya study, cepat bercerai karena masih belum cukup umur dan ekonomi sulit disebabkan tidak bekerja. Namun anak berhak menyelamatkan dirinya dari perzinaan. Perilaku seks bebas yang dilakukan remaja modern baik dengan pasangannya (pacar) maupun dengan kekasih gelapnya menambah kasus remaja hamil di luar nikah. Mengakibatkan tingginya proses permintaan aborsi, kasus pembuangan bayi dan lebih parah adalah menikahkan anak sebelum kandungannya membesar atau lebih dikenal MBA (married by accident).

Menikahkan anak karena "kecelakaan" sudah menjadi tren dan budaya. Zina sudah dianggap "zamannya". Akibat "pernikahan dini" tersebut akan lahir bayi-bayi luar biasa karena yang dikandung lebih pendek waktunya. Bisa dibayangkan seorang wanita yang baru nikah enam bulan sudah melahirkan.

Untuk menikah dini memang tidaklah mudah. Terlebih lagi ekonomi Indonesia yang tengah terpuruk, dianggap akan menyulitkan kehidupan rumah tangga. Namun tanpa disadari 
bahwa keterpurukan ini muncul sebagai akibat mentalitas rakyat Indonesia yang senang topang dagu, cenderung malas berpikir keras untuk menciptakan lapangan kerja sendiri.

\section{METODE PENELITIAN}

Dalam penelitian ini peneliti menggunakan metode penelitian kualitatif dengan alasan karena permasalahan dalam penelitian ini sangat luas (Holistik). Penelitian Kualitatif menurut Moleong adalah penelitian yang bermaksud untuk memahami fenomena tentang apa yang dialami oleh subyek penelitian secara bolistik dengan cara deskriptif dalam bentuk kata-kata dan bahasa pada suatu konteks, khususnya yang alamiah dengan memanfaatkan berbagai metode alamiah. ${ }^{2}$ Jadi berdasarkan waktu yang telah ditentukan, peneliti bermaksud mendalami situasi sosial masyarakat telebih dahulu, teori, serta pola-pola masyarakat di daerah yang dijadikan obyek penelitian secara mendalam sehingga permasalahannya menjadi jelas. Jenis pendekatan penelitian ini menggunakan pendekatan studi kasus. menurut Arikunto, penelitian studi kasus adalah penelitan yang dilakukan secara intensif, terinci dan mendalam terhadap suatu organisasi, lembaga atau gejala tertentu. ${ }^{3}$

Dalam penelitian kualitatif peneliti merupakan instrumen penelitian, sehingga peneliti memiliki peranan penuh dalam kegiatan penelitian. Peneliti yang berstatus sabagai instrumen juga harus di validasi melaui tingkat pemahaman peneliti ketika terjun kelapangan. Dan bagaimana tingkat pemahaman peneliti terhadap metode penelitian, penguasaan pada obyek yang sedang diteliti, serta kesiapannya ketika terjun kelapangan.

Adapaun Dalam penelitian ini untuk memperoleh data, peneliti menggunakan tekhnik wawancara yang di bantu dengan alat-alat seperti kamera, video, perekam dll dengan tujuan untuk bukti serta menguji kevalidan data.

Dalam penelitian ini peneliti dalam menganalisis data pada dasarnya bersamaan dengan pengumpulan data. Jadi ketika peneliti sudah terjun kelapangan kemudian membuat fokus, membuat tema kemudian mengumpulkan data-data penelitian, yang dilakukan dengan menggunakan wawancara, observasi, dokumentasi kemudian triangulasi data yang di bantu dengan berbagai alat sebagai salah satu uji validitas. Kemudian hasil penelitian tersebut diproses melalui reduction, data dislay yang tahap akhirnya yaitu tahap verifikasi.

\section{HASIL PENELITIAN DAN PEMBAHASAN}

\section{Pernikahan Dini menurut Pandangan Islam}

Hukum Islam secara umum meliputi lima prinsip yaitu perlindungan terhadap agama, jiwa, keturunan, harta, dan akal. Dari kelima nilai universal Islam ini, satu diantaranya adalah

${ }^{2}$ Lexy Moleong, Metode Penelitian Kualitatif, ( Bandung: Remaja Rosdakarya, 2006), h. 6.

3 Suharsimi Arikunto, Prosedur Penelitian Suatu Pendekatan Praktek: EdisiRevisi V, Jakarrta: Rineka Cipta, 2002), h. 12. 
agama menjaga jalur keturunan (bifdzu al nas). Oleh sebab itu, Syekh Ibrahim menuturkan bahwa agar jalur nasab tetap terjaga, hubungan seks yang mendapatkan legalitas agama harus melalui pernikahan. Seandainya agama tidak mensyari'atkan pernikahan, niscaya geneologi (jalur keturunan) akan semakin kabur. ${ }^{4}$

Agama dan negara terjadi perselisihan dalam memaknai pernikahan dini. Pernikahan yang dilakukan melewati batas minimnal Undang-undang Perkawinan, secara hukum kenegaraan tidak sah. Istilah pernikahan dini menurut negara dibatasi dengan umur. Sementara dalam kaca mata agama, pernikahan dini ialah pernikahan yang dilakukan oleh orang yang belum baligh.

Terlepas dari semua itu, masalah pernikahan dini adalah isu-isu kuno yang sempat tertutup oleh tumpukan lembaran sejarah. Dan kini, isu tersebut kembali muncul ke permukaan. Hal ini tampak dari betapa dahsyatnya benturan ide yang terjadi antara para sarjana Islam klasik dalam merespons kasus tersebut. Agama melarang pernikahan dini (pernikahan sebelum usia baligh). Menurutnya, nilai esensial pernikahan adalah memenuhi kebutuhan biologis, dan melanggengkan keturunan. Sementara dua hal ini tidak terdapat pada anak yang belum baligh. Ia lebih menekankan pada tujuan pokok pernikahan.

Ibnu Syubromah mencoba melepaskan diri dari kungkungan teks. Memahami masalah ini dari aspek historis, sosiologis, dan kultural yang ada. Sehingga dalam menyikapi pernikahan Nabi Saw dengan Aisyah (yang saat itu berusia usia 6 tahun), Ibnu Syubromah menganggap sebagai ketentuan khusus bagi Nabi Saw yang tidak bisa ditiru umatnya

Sebaliknya, mayoritas pakar hukum Islam melegalkan pernikahan dini. Pemahaman ini merupakan hasil interpretasi dari QS. al Thalaq: 4. Disamping itu, sejarah telah mencatat bahwa Aisyah dinikahi Baginda Nabi dalam usia sangat muda. Begitu pula pernikahan dini merupakan hal yang lumrah di kalangan sahabat. Bahkan sebagian ulama menyatakan pembolehan nikah dibawah umur sudah menjadi konsensus pakar hukum Islam. Wacana yang diluncurkan Ibnu Syubromah dinilai lemah dari sisi kualitas dan kuantitas, sehingga gagasan ini tidak dianggap. Konstruksi hukum yang di bangun Ibnu Syubromah sangat rapuh dan mudah terpatahkan. ${ }^{5}$

Imam Jalaludin Suyuthi pernah menulis dua hadis yang cukup menarik dalam kamus hadisnya. Hadis pertama adalah "Ada tiga perkara yang tidak boleh diakhirkan yaitu shalat ketika datang waktunya, ketika ada jenazah, dan wanita tak bersuami ketika (diajak menikah) orang yang setara/kafaah". ${ }^{6}$ Hadis Nabi kedua berbunyi, "Dalam kitab taurat tertulis bahwa

\footnotetext{
${ }^{4}$ Ibrahim, al Bajuri, vol. 2, (Toha Putra, Semarang, 2006), h. 90.

5 Ibnu Hajar al 'Asqalani, Fathul Bari vol. Darul Kutub Ilmiah, Beirut. 9 h.237.

6 Jalaluddin Suyuthi, Jami’ al Shaghir, Darul Kutub Ilmiah, Beirut. h.210.
} 
orang yang mempunyai anak perempuan berusia 12 tahun dan tidak segera dinikahkan, maka anak itu berdosa dan dosa tersebut dibebankan atas orang tuanya". ${ }^{7}$

Pada hakekatnya, penikahan dini juga mempunyai sisi positif. Kita tahu, saat ini pacaran yang dilakukan oleh pasangan muda-mudi acapkali tidak mengindahkan norma-norma agama. Kebebasan yang sudah melampui batas, akibat kebebasan itu kerap kita jumpai tindakantindakan asusila di masyarakat. Fakta ini menunjukkan betapa moral bangsa ini sudah sampai pada taraf yang memprihatinkan. Hemat penulis, pernikahan dini merupakan upaya untuk meminimalisir tindakan-tindakan negatif tersebut. Daripada terjerumus dalam pergaulan yang kian mengkhawatirkan, jika sudah ada yang siap untuk bertanggungjawab dan hal itu legal dalam pandangan syara' kenapa tidak?

Substansi hukum Islam adalah menciptakan kemaslahatan sosial bagi manusia pada masa kini dan masa depan. Hukum Islam bersifat humanis dan selalu membawa rahmat bagi semesta alam. Apa yang pernah digaungkan Imam Syatiby dalam magnum opusnya ini harus senantiasa kita perhatikan. Hal ini bertujuan agar hukum Islam tetap selalu up to date, relevan dan mampu merespon dinamika perkembangan zaman. ${ }^{8}$

Permasalahan berikutnya adalah baik kebijakan pemerintah maupun hukum agama sama-sama mengandung unsur maslahat. Pemerintah melarang pernikahan usia dini adalah dengan pelbagai pertimbangan di atas. Begitu pula agama tidak membatasi usia pernikahan, ternyata juga mempunyai nilai positif. Sebuah permasalahan yang cukup dilematis.

Menyikapi masalah tersebut, penulis teringat dengan gagasan Izzudin Ibn Abdussalam dalam bukunya Qowa'id al Ahkam. Beliau mengatakan jika terjadi dua kemaslahatan, maka kita dituntut untuk menakar mana maslahat yang lebih utama untuk dilaksanakan. ${ }^{9}$

Kaedah tersebut ketika dikaitkan dengan pernikahan dini tentunya bersifat individualrelatif. Artinya ukuran kemaslahatan di kembalikan kepada pribadi masing-masing. Jika dengan menikah usia muda mampu menyelamatkan diri dari kubangan dosa dan lumpur kemaksiatan, maka menikah adalah alternatif terbaik. Sebaliknya, jika dengan menunda pernikahan sampai pada usia "matang" mengandung nilai positif, maka hal itu adalah yang lebih utama.

\section{Dampak Pernikahan Dini}

a. Rendahnya Sumber Daya Manusia

Rendahnya pendidikan remaja sono berakibat pada rendahnya Sumber Daya Manusia. Keputusan untuk nikah di usia masih muda membuat seseorang tidak bisa melanjutkan pendidikannya ke jenjang yang lebih tinggi kemudian sudah memutuskan

7 Ibid., h.501.

8 Imam Syatibi, al Munafaqot, Darul Kutub Ilmiah, Beirut. h.220

9 Izzudin Ibn Abd. Salam, Qowa’id al Ahkam, vol.II Darul Kutub Ilmiah, Beirut. h.90 
untuk berkeluarga, hal tersebut menandakan tindakan yang benar, sebab jika sudah berkeluarga membuat mereka tidak ada kesempatan untuk mengembangkan diri karena rasa tanggung jawab dalam keluarga harus dan harus mengurus keluarga serta mencari nafkah untuk keluarganya.

.....dikarenakan pendidikan yang rendah, kemudian menikah di usia yang masih sangat muda, maka berakibat pada rendabnya kualitas Sumber Daya Manusia warga sono. Mayoritas warga sini banya sebagai petani, burub tambang ke kalimantan dan balak kayu di jambi. La..gimana wong pendidikan mereka rendah..... ${ }^{10}$

Pendidikan memiliki peranan besar dalam meningkatkan Sumber Daya Manusia demi menyongsong perkembangan Ilmu Pengetahuan dan Teknologi. Pendidikan memberikan kemampuan untuk berkembang lewat penguasaan ilmu dan keterampilan. Warga Sono yang mayoritas warganya hanya lulusan SD dan SMP bisa dikatakan sangat tertinggal dengan daerah-darah lain. Pendidikan yang rendah menyulitkan mereka untuk berkompetisi dengan orang lain. Bahkan beberapa di antara mereka masih buta tekhnologi dan tidak bisa mendapatkan pekerjaan yang layak.

b. Meningkatnya angka buruh perantauan

Salah satu alasan mereka merantau adalah karena berkurangnya lapangan pekerjan di daerah asal didukung dengan latar belakang pendidikan yang rendah, sedangkan mereka dituntut untuk memenuhi kebutuhan keluarganya akibat menikah di usia muda, memaksa mereka untuk bekerja sebagai buruh di perantauan.

Selain lapangan pekerjan, pendidikan dan perkawinan memegang peranan penting sebagai faktor penyebab terjadinya peningkatan angka buruh ke luar daerah. Alasan utama yang disampaikan oleh mayoritas warga adalah karena pekerjan bertani atau buruh tani penghasilanya tidak lagi bisa mencukupi kebutuhan mereka. Tuntan ekonomi yang lebih dari keluarganya menyebabkan sebagian besar masyarakatnya memilh untuk merantau sebagai buruh tambag dan buruh pembalakan di luar jawa.

Dampak pernikahan dini dapat ditinjau dari dua segi, antara lain; dampak fisik dan dampak psikologis ${ }^{11}$, sebagai berikut:

\section{Dampak Fisik}

a). Ekonomi Rumah Tangga

Pasangan usia muda belum mampu dibebani suatu pekerjaan yang memerlukan keterampilan fisik, untuk mendatangkan penghasilan baginya, dan mencukupi

10 Wawancara dengan salah satu guru SD setempat, 10 oktober 2014

${ }^{11}$ Hartati, Dian Aprilia, Dampak Fisik dan Psikologi Pernikahan Dini http:// dianapriliahartanti.w ordpress.com., (diakses tanggal 20 Juni 2013) 
kebutuhan keluarganya. Faktor ekonomi adalah salah satu faktor yang berperan dalam mewujudkan kesejahteraan dan kebahagiaan rumah tangga.

b). Kanker leher rahim

Perempuan yang menikah dibawah umur 20 tahun beresiko terkena kanker leher rahim. Pada usia remaja, sel-sel leher rahim belum matang. Kalau terpapar human papiloma virus atau HPV pertumbuhan sel akan menyimpang menjadi kanker.

c). Resiko Tinggi Ibu Hamil

Dilihat dari segi kesehatan, pasangan usia muda dapat berpengaruh pada tingginya angka kematian ibu yang melahirkan, kematian bayi serta berpengaruh pada rendahnya derajat kesehatan ibu dan anak. Menurut ilmu kesehatan, bahwa usia yang kecil resikonya dalam melahirkan adalah antara usia 20-35 tahun, artinya melahirkan pada usia kurang dari 20 tahun dan lebih dari 35 tahun mengandung resiko tinggi. Ibu hamil usia 20 tahun ke bawah sering mengalami prematuritas (lahir sebelum waktunya) besar kemungkinan cacat bawaan, fisik maupun mental, kebutaan dan ketulian.

\section{Dampak Psikologis}

a. Neoritis depresi

Depresi berat atau neoritis depresi akibat pernikahan dini ini, bisa terjadi pada kondisi kepribadian yang berbeda. Pada pribadi introvert (tertutup) akan membuat si remaja menarik diri dari pergaulan. Dia menjadi pendiam, tidak mau bergaul, bahkan menjadi seorang yang schizoprenia atau dalam bahasa awam yang dikenal orang adalah gila. Sedang depresi berat pada pribadi ekstrovert (terbuka) sejak kecil, si remaja terdorong melakukan hal-hal aneh untuk melampiaskan amarahnya. Seperti, perang piring, anak dicekik dan sebagainya. Dengan kata lain, secara psikologis kedua bentuk depresi sama-sama berbahaya. Usia masih terlalu muda, banyak keputusan yang diambil berdasar emosi atau mungkin mengatasnamakan cinta yang membuat mereka salah dalam bertindak. Meski tak terjadi Married By Accident (MBA) atau menikah karena "kecelakaan", kehidupan pernikahan pasti berpengaruh besar pada remaja. Oleh karena itu, setelah dinikahkan remaja tersebut jangan dilepas begitu saja.

b. Konflik yang berujung perceraian

Sibuknya seorang remaja menata dunia yang baginya sangat baru dan sebenarnya ia belum siap menerima perubahan ini. Positifnya, ia mencoba bertanggung jawab atas hasil perbuatan yang dilakukan bersama pacarnya. Hanya satu persoalannya, pernikahan usia dini sering berbuntut perceraian. Kestabilan emosi umumnya terjadi pada usia 24 tahun, karena pada saat itulah orang mulai memasuki usia dewasa. Masa remaja, boleh di bilang baru berhenti pada usia 19 tahun. Dan pada usia 20 - 24 tahun dalam psikologi, dikatakan sebagai usia dewasa muda atau lead 
edolesen. Pada masa ini, biasanya mulai timbul transisi dari gejolak remaja ke masa dewasa yang lebih stabil. Maka, kalau pernikahan dilakukan di bawah 20 tahun secara emosi si remaja masih ingin bertualang menemukan jati dirinya.

\section{SIMPULAN}

Substansi hukum Islam adalah menciptakan kemaslahatan sosial bagi manusia pada masa kini dan masa depan. Hukum Islam bersifat humanis dan selalu membawa rahmat bagi semesta alam. Apa yang pernah digaungkan Imam Syatiby dalam magnum opusnya ini harus senantiasa kita perhatikan. Hal ini bertujuan agar hukum Islam tetap selalu up to date, relevan dan mampu merespon dinamika perkembangan zaman. Dampak pernikahan dini di dusun sono antara lain; Terhindar dari perbuatan zina, rendahnya pengetahuan warga sono akan perkembangan IPTEK dan Sumber Daya Manusia, meningkatnya angka pengagguran berdampak pada meningkatnya angka perantauan ke luar daerah.

\section{DAFTAR PUSTAKA}

Ahmad Azhar Basir. Hukum Perkawinan Islam, Yokyakarta, UII Press, 1997

al 'Asqalani, Ibnu Hajar. Fathul Bari vol. Beirut :Darul Kutub Ilmiah

Ali Trigiyatno, Pernikahan Dini; Perspektif Fiqh Munakahat Dan Hukum Positif Di Indonesia. diakses tanggal 12 Januari 2013

BKKBN, Kajian Pernikahan Dini Pada Beberapa Provinsi Di Indonesia: Dampak Overpopulation, Akar Masalah Dan Peran Kelembagaan Di Masalah Dan Peran Kelembagaan Di Daerah.2010

Hartati, Dian Aprilia Dampak Fisik dan Psikologi Pernikahan Dini, http:// dianapriliahartanti.wordpress.com. diakses tanggal 20 Juni 2013.

http:/ /www.docstoc.com. Pernikahan-Dini-pengertian-dan-motif. diakses tanggal 4 April 2013 Ibrahim. al Bajuri. vol. 2. Semarang Toha Putra, 2014

Imam Syatibi, AlMunafaqot. Beirut: Darul Kutub Ilmiah

Jalaluddin SuyuthI, Jami' al Shaghir . Beirut: Darul Kutub Ilmiah, 2008

Lexy Moleong, Metode Penelitian Kualitatif. Bandung, Remaja Rosdakarya, 2009.

Salam, Abs. dan Izzudin Ibn. Qowa’id al Abkam. vol.II. Beirut: Darul Kutub Ilmiah

Suharsimi Arikunto, Prosedur Penelitian Suatu Pendekatan Praktek: Edisi Revisi V. Jakarrta: Rineka Cipta, 2002.

Undang-Undang Republik Indonesia Tentang Perkawinan Nomor 1 ayat 1 Tahun 